\author{
Kamil Waligóra \\ University of Bialystok \\ Poland \\ e-mail: kamilwaligora@tlen.pl
}

\begin{abstract}
The paper presents the effects of the approach of the BRIC countries' authorities (Brazil, Russia, India and China) to the issues of growth, development and social satisfaction. The aim was to establish which of the BRIC countries best used the favorable economic conditions for achievement of social objectives. The paper shows the results of reasearches on a correlation between the assessment of quality of life of the population and growth as well as economic development on the example of the BRIC countries. Comparison of qualitative and quantitative (from economic to psychological) indicators allowed to evaluate the effectiveness of governments' policies. As a result of the analysis, the author stated that a steady increase in income is essential and should be used by the authorities of the state to ensure the development and to satisfy the needs of the society. In the last three decades, BRIC achieved dynamic economic growth, which in different ways influenced the socio-economic development. Consequently, only Brazil used the economic growth properly to improve the social and living conditions of the population, which had an effect on the level of the happiness of the society.
\end{abstract}

Received:

February, 2015

1st Revision:

April, 2015

Accepted:

May, 2015

DOI:

$10.14254 / 2071$ $8330.2015 / 8-1 / 10$

Keywords: growth, development, happiness, BRIC, developed society

JEL Classification: E2, F43, F63, F64, I31, I38, O11, O21, O4

\title{
INTRODUCTION
}

Economic growth has become a major objective of the policies of governments of many countries. (Vaury, 2003, pp. 38-40) Measured primarily by GDP and its variants, it caused the issues of development and quality of life descend into the background. The situation changed only in the late 20th century, especially in the countries considered to be developed. (Costanza, Hart, Posner, Talberth, 2009)

The BRIC countries (Brazil, Russia, India, China) are classified as developing countries. (Tamazian, Piñeiro Chousa, Chaitanya Vadlamannati) Despite their growing role in the global economy, these countries are yet to form their models of growth and development. Due to the size of their markets (approx. 40 percent of the world's population), dynamic growth and increasing consumption, BRIC has a strong impact on the global economy. For this reason, changes in these countries should be monitored. 
The aim of this article is to analyze the correlation between the assessment of the quality of life of the population and the indicators of growth and economic development on the example of the BRIC countries. It was assumed that an increase in quality of life of the population (three measures: Human Development Index, GDP per capita and Happy Planet Index) ${ }^{1}$ does not depend directly on the size of Gross Domestic Product. The governments' policies of the BRIC countries will also be evaluated in order to establish which country used the favorable economic conditions best.

The analysis was based on proven and recognized sources of international statistics well as on the results of research by foundations and international organizations. The majority of the data come from the 20082012 period (mid-term analysis, after the financial crisis of 2007). Using different forms of presentation along with combining the indicators allowed to determine trends of change of the indicators. Furthermore, it was determined which of the BRIC countries properly took advantage of favorable economic conditions. The final evaluation was based on the psychological indicators.

The main objective of the public authorities in each country should be to foster the development, satisfaction and social fulfillment. Naturally, this is accomplished by redistributing the proceeds from the country concerned. Therefore, effective use of the resources to solve social issues is essential. (Bastiat, 1964, p.111) and should be the basis for the assessment of the development of the country and the effectiveness of the public authorities.

Numerous international institutions start to notice the disadvantages of GDP as a key indicator of both economic growth and development of the society. (http://www.eu-territorial-agenda.eu/Reference\%20 Documents/updated\%20Territorial\%20State\%20and\%20Perspective\%20of\%20the\%20EU_May_2011_ FINAL.pdf, 12/02/2015) Therefore it is advisable to search for indicators other than GDP, or at least to supplement it with new, more effective indicators.

The first part of the article presents definitions which emphasize differences and correlations between growth and development as well as the definition of a developed society. In the following part, the author indicates the items that have been of crucial importance for the growth of the BRIC economies in recent years, including internal and external factors. The changes in selected indicators of the growth, development and quality of life in the BRIC societies are analyzed. The author will discuss GDP as well as other, more qualitative indicators, e.g. Human Development Index, Happy Planet Index, and the most subjective World Happiness Report. Such a comparison will enable the verification of the assumptions. As a reference, the author will use a group of countries considered as developed. The last part will present conclusions with the evaluation which of the BRIC countries best used the favorable economic conditions for achievement of social objectives.

\section{THEORETICAL INTRODUCTION}

Separation of growth and development is crucial. State authorities often use the indicators of growth, trying to show that „life is better” in a certain country. Demarcation of the two concepts is therefore indispensable.

"Growth" is primarily associated with increase, escalation, lifting, enlarging. (Stownik wspótczesnego jezyka polskiego, 1998) At the economic level, growth is understood as an increase in economic indicators. As a part of economy, "economic growth" is mostly growth of products produced: by the society (Gross Na-

1 Human Development Index (HDI), GDP per capita (ppp), Happy Planet Index (HPI) 
tional Product), in the country (Gross Domestic Product). GDP 2 , GNP ${ }^{3}$ and $\mathrm{NI}^{4}$ have mostly unidirectional changes - convergence of the trends in the long term. (Samuelson, 2012, pp. 402-405; Milewski, 1999, pp. 244-252; Cameron, 2001, pp. 12-13)

"Growth" refers to quantitative changes and mainly makes it different from "development". It is a reversible process, which is the opposite of "economic decline". (Cameron, 2001, p. 11)

"Development" is a term used to describe a long-term process of directional changes that can be divided into stages, during which there is a differentiation of the object at the specified terms. Transitioning from simpler to more complex forms occurs. (Wielka encyklopedia powszechna PWN, 1968, p. 148) In the case of countries it is reflected, inter alia, in the evolution of structures, both economic and socio-political. (Bossak, 2006, pp. 13-15)

Economic development is economic growth preceded by/connected with/completed by operations of an institutional or organizational character. (Nowa encyklopedia powszechna PWN, 1998, p. 616) The effect of economic development is a change of a qualitative nature, e.g. improvement of the quality of the environment or schooling, modification of the share of individual sectors in the economy (increasing role of industry and, subsequently, services).

It is much easier to achieve economic growth than development, because growth is more objective and measurable. Development is related with measurable and immeasurable (more subjective) factors. Therefore, some societies at a given level of economic growth achieve higher levels of life satisfaction than those whose income per capita is currently much higher.

So, what is a developed society? It can be defined as one in which further economic growth does not lead to an increase in personal satisfaction (ceteris paribus). Thus, there has been an exhaustion development opportunities - a society in a given space and time reached the maximum level of satisfaction (highest aggregate total utility). This is visible in societies considered to be developed, e.g. in Sweden, Denmark and Norway, where the current level of wealth leads to a reduction of working hours so that the people could satisfy their social/family needs. Society ceases to depend on the continued growth and "getting rich" in purely material terms.

\section{BRIC - GROWTH OR DEVELOPMENT?}

In the last three decades, BRIC achieved dynamic economic growth due to both their internal potential and favorable external factors. The authorities of the group members rightly recognized that growth requires, inter alia, access to capital and global markets. As a result of insufficient internal resources and costly reforms (Brazil after 1985, Russia after 1991, India after 1980, China after 1978), the countries ought external funding. Foreign capital (in the form of loans, direct and indirect investments, etc.) flowed in the time of political stability and the occurrence of favorable medium-term prospects for development.

The BRIC established export promotion policies to encourage foreign investments. Finally, in each of the BRIC countries there has been a deregulation of the economy, reducing (to a lesser or greater extent) the public sector's share in GDP. Global processes were very important for economic growth: the internationalization of economies and enterprises, the elimination of a number of trade barriers, globalization and rise of social entrepreneurship.

2 Gross Domestic Product.

Gross National Product.

National Income. 
Important factors supporting the continued growth of the BRIC were the development of ICT and transport. Flowing capital was willingly placed on stable and large markets with potential in population (China and India), characterized by a relatively diverse education and low labor cost. Global growth intensified the demand for raw materials and agricultural goods (Russia and Brazil). So the last decades of the 20th century and the beginning of the 21st century supported the growth of these economies. (O'Neill, 2001, pp. 9-11) It is worth considering whether the authorities of this group used the favorable conditions and led to the development and growth of social satisfaction.

The development of the BRIC societies was particularly visible in the case of Brazil and China. The first of these countries has taken the arduous process of improving the living conditions of the population. In Brazil, more than 40 million people (more than $20 \%$ of the total population) significantly improved living conditions in the first decade of the twenty-first century. This was due to a strategy based on the redistribution of income in such a way to support families who send their children to school. This social design allowed the improvement of living conditions with an increase in the level of education.

In China, the government focused on economic growth, recognizing that it will become a source of change also in the social sphere and living conditions. The policy has led to, among others, the migration of people from rural to urban areas (to work and improve the material status), the growth of the middle class and increased consumption. (http://www.chinabusinessreview.com/understanding-chinas-middle-class/, 17/02/2015)

Russian authorities seem to have performed the worst form the BRIC countries. In addition to the standard mechanisms of redistribution of income, which is more effective in maintaining the status quo than in contributing to the improvement of the living conditions of the poorest, no strategic program in the social sphere has been developed and implemented. After the annexation of the Crimea (2014) and imposition of sanctions on Russia (by the US, the EU and other developed countries) and the drastic fall in oil prices on world markets (http://natemat.pl/120697,ropa-tanieje-spadki-cen-zabija-rosyjska-gospodarke-rosja-mozeprzez-to-stracic-nawet-1-2-proc-pkb, 20/02/2015), the poorer part of the population was strongly hit by the economic downturn.

Analysis of such a diverse group as the BRIC countries (Waligóra, 2011; Waligóra, 2012) require an adoption of universal indicators. Economic growth will be analyzed primarily through the prism of GDP. Development, according to the definition and some difficulty of measurement, will be represented by three indicators: GDP per capita, HDI (Human Development Index) ${ }^{5}$ and HPI (Happy Planet Index) ${ }^{6}$. The years 2008, 2009, 2010, 2011, 2012 were chosen for the analysis. The period could be longer (which would allow a more accurate determination of the impact of public policies on growth and economic development), but the data available for the last indicator contributed to its limitation. A crucial role will be played by the changes in individual indicators and convergence/divergence of the trends. The control group consists of three countries considered to be developed: Germany, Norway, the USA.

Economic growth measured by the change of GDP (Table 1) in the BRIC countries during the period had a higher dynamics than in the developed countries. It should be noted, however, that the minimum income change (in absolute terms) in the wealthiest countries in the world may be higher than the percentage change in GDP in the countries on the lower level of development (despite higher growth). Thus, it is not the best indicator. Comparison of absolute values is also not justified because of the varying size of the analyzed countries.

\footnotetext{
Indicator developed in 1990 by Pakistani economist Mahbub ul Haq. Since 1993 used by United Nations Development Programmein their annual reports.

${ }^{6}$ Indicator created in 2006 by the New Economics Foundation (NEF) to measure the level of well-being in individual countries.
} 
GDP growth (in \%)

\begin{tabular}{|l|c|c|c|c|c|}
\hline \multirow{2}{*}{ Country } & \multicolumn{5}{|c|}{ Gross Domestic Product growth (change in percentage -annual growth in US dollars; 2005) } \\
\hline & 2008 & 2009 & 2010 & 2011 & 2012 \\
\hline Brazil & 5,2 & $-0,3$ & 7,5 & 2,7 & 1,0 \\
\hline Russia & 5,2 & $-7,8$ & 4,5 & 4,3 & 3,4 \\
\hline India & 3,9 & 8,5 & 10,3 & 6,6 & 4,7 \\
\hline China & 9,6 & 9,2 & 10,4 & 9,3 & 7,7 \\
\hline Germany & 1,1 & $-5,6$ & 4,1 & 3,6 & 0,4 \\
\hline Norway & 0,1 & $-1,6$ & 0,5 & 1,3 & 2,9 \\
\hline the USA & $-0,3$ & $-2,8$ & 2,5 & 1,6 & 2,3 \\
\hline
\end{tabular}

Source: Global Bank statistics, // http://data.worldbank.org/indicator/NY.GDP.MKTP.KD.ZG // (accessed on 11/01/2015).

In 2009 economic decline has affected many economies. In the table above, only two did not have a negative growth rate, and these were China and India. Large internal markets with unsatisfied basic needs remained their strength. This and much lower initial level of GDP and GDP per capita (Graph 1) allowed to protect themselves against economic decline.

Each of the BRIC countries used the period of economic downturn in a different way. Most implemented changes that were to contribute to improving the competitiveness of the country. The crisis has become a catalyst for change and forced the further reforms, including the influence on the development strategies.

The Chinese authorities seem to be aware of the changes taking place in their society. They take steps to modify the economy towards domestic consumption. Along with the enrichment of the population, the proportions in the trade balance are being reversed. China export less, while the middle class claims further needs. (Barton, Chen Jin, 2013) Also, social trends (decreasing number of people in pre-working age) make maintaining the growth require a reorganization of the economic system.

Russia and India, despite their theoretically long-term economic development strategies seem to develop accidentally. In Russia, social development is shaped by the structure of the party and the state. This causes more and stronger stratification. Authorities in India, because of the functioning caste system, do not treat the public as one organism. A policy of encouraging foreign companies to outsource which allowed the formation of "the poor" middle class and enrichment of the higher castes had a positive impact on society. Still, such a large diversity has a negative impact on the self-esteem of the society as well as on the family life satisfaction and work. (http://www.thehindu.com/opinion/op-ed/being-middle-class-in-india/ article6673580.ece, 19/02/2015)

Since coming to power by Dilma Rousseff, Brazil does not seem to have an idea for further growth. Moving tens of millions of people upwards the income pyramid and strengthening the science sector needs to find a new place for the Brazilian economy in the global system. Cost advantage in recent years significantly decreased. Unfortunately, at this time, the ICT sector was not strengthened enough. Only large companies (e.g. Embraer - aircraft manufacturer, or Petrobras - oil company) with the support of the government could invest in the international market, building a recognizable brand. 


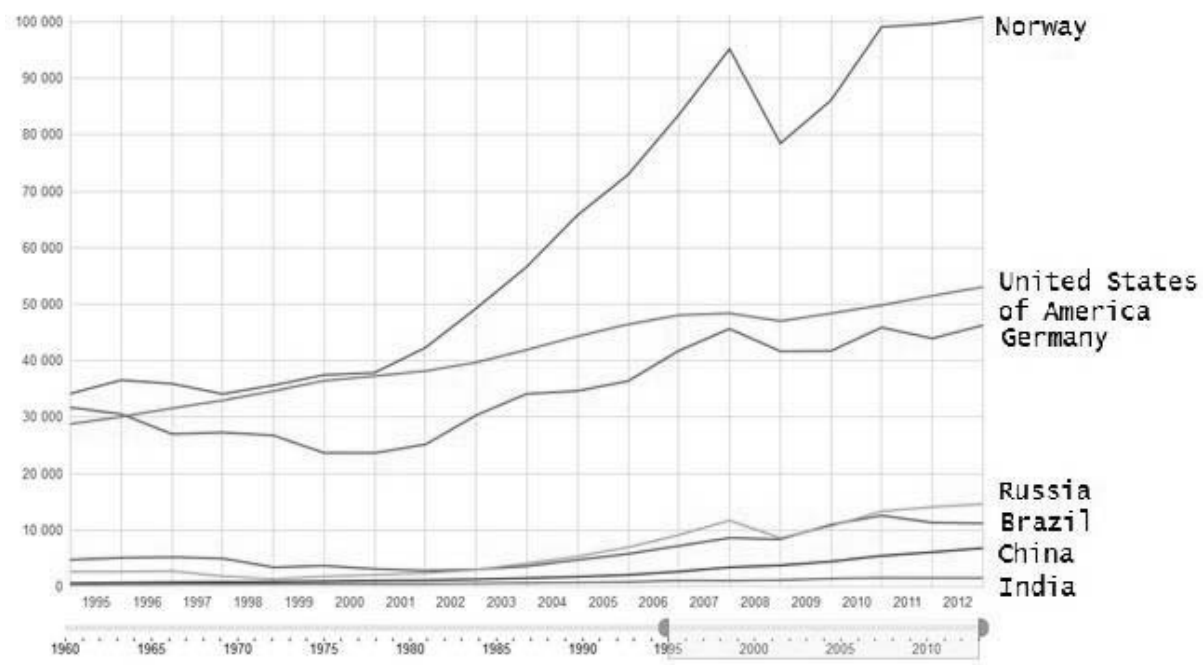

Graph 1. GDP per capita in current US dollars

Source: Global Bank statistics // http://www.google.us/publicdata/explore?ds=d5bncppjof8f9_\&met_y=ny_gdp_mktp_ cd\&idim=country:POL:UKR:NOR\&hl=pl\&dl=pl\#!ctype=l\&strail=false\&bcs=d\&nselm=h\&met_y=ny_gdp_pcap_ cd\&scale_y=lin\&ind_y=false\&rdim=region\&idim=country:NOR:DEU:RUS:BRA:CHN:IND:USA\&ifdim=region\&t start=793062000000\&tend=1361142000000\&hl=pl\&dl=pl\&ind=false // (accessed on 11/01/2015).

The first indicator related to development is GDP per capita (Table 2, Graph 1). Theoretically, it is a reflection of changes in the standard of living of the test population by GDP. Due to the inclusion of the population in relation to changes in the product, with its help, changes in the medium-term trends and the effectiveness of economic policy can be effectively analyzed.

Within the BRICS, the most stable increase in GDP per capita was reached by China. Stabilization of the population, with a steady economic growth leads to ever higher levels of the population income. Indian GDP per capita growth is limited by the dynamically growing number of people (in the 60s of the 20th century, one woman gave birth to six children on average, at the end of the age - to approx. 2.5 children). Besides, India has a smaller and more diverse middle class (than China). In the long term, the middle class is responsible for the overall development of the society.

Table 2

GDP per capita (\%)

\begin{tabular}{|l|c|c|c|c|c|}
\hline \multicolumn{1}{|c|}{ Country } & \multicolumn{5}{|c|}{ GDP per capita, PPP (current international \$) } \\
\hline & 2008 & 2009 & 2010 & 2011 & 2012 \\
\hline & 2 & 3 & 4 & 5 & 6 \\
\hline Brazil & 4,2 & $-1,2$ & 6,6 & 1,8 & 0,2 \\
\hline Russia & 5,4 & $-7,8$ & 4,2 & 3,8 & 3,3 \\
\hline India & 2,5 & 7,1 & 8,8 & 5,3 & 3,4 \\
\hline China & 9,1 & 8,7 & 9,9 & 8,8 & 7,1 \\
\hline Germany & 1,2 & $-5,4$ & 4,3 & 3,6 & 2,1 \\
\hline
\end{tabular}




\begin{tabular}{|l|c|c|c|c|c|}
\hline 1 & 2 & 3 & 4 & 5 & 6 \\
\hline Norway & $-1,2$ & $-2,9$ & $-0,8$ & 0,0 & 1,6 \\
\hline the USA & $-1,2$ & $-3,7$ & 1,7 & 0,9 & 1,6 \\
\hline
\end{tabular}

Source: Global Bank statistics; // http://data.worldbank.org/indicator/NY.GDP.MKTP.KD.ZG // (accessed on $12 / 01 / 2015)$.

In developed countries, the percentage increase in income is much lower, which can be explained by, among others, a high level of stability and development of the society. Crisis (and fluctuations) affected mostly Brazil and Russia, and the developed countries of Western Europe and the United States (including the control group). Low growth rate of GDP per capita in Europe and the US can also indicate the limits of the current development of these societies.

Another indicator chosen for the analysis is Human Development Index (HDI). It is an index describing the effects of the current government policies in the field of socio-economic development. (http:// hdr.undp.org/en/content/table-2-human-development-index-trends-1980-2013, 02/08/2015) It combines strictly economic elements with social prospects.

The indicator includes three areas: life expectancy at birth, the average number of years of education received by the population aged 25 years and older, and national income per capita in US dollars, calculated according to purchasing power parity of the currency (USD PPP). HDI data are presented for the studied countries for the period 2008-2012 (Table 3).

In the BRIC countries, in the considered period, the fastest positive changes in the HDI occurred in China and India. 1.5\% HDI change compared to the control group is relatively high. Both India and China still have distant places in the classification (93 and 135 respectively), so they still have a considerably large gap to level up in relation to the developed societies.

In China, rapidly growing income per capita had a greater impact on the final value of HDI. In India, even a small improvement in the living conditions of the population resulted in the improvement of the indications regarding life expectancy. In Brazil and Russia, the change in HDI also based on improvement of the living conditions and income growth. From the control group, Germany had a comparable percentage increase to Russia and Brazil. It should be noted, however, that the overall standard of living in Germany is incomparably higher than in Russia or Brazil. Consistently, Norway remained the leader of the ranking.

Finally, based on past statements it can be concluded that the policy of the Chinese authorities results in the best (economic) effects. In BRIC, the Chinese society is increasing its wealth the fastest, which is also reflected in the length of life, health, etc. Material and living conditions are improving very fast in China.

Table 3

Human Development Index: 2008, 2010, 2011 and 2012 (selected countries)

\begin{tabular}{|c|c|c|c|c|c|c|c|c|}
\hline \multirow[b]{2}{*}{ Country } & \multicolumn{8}{|c|}{ Human Development Index (score in the range of $0-1$; the closer to 1 , the better) } \\
\hline & 2008 & 2009 & 2010 & 2011 & 2012 & $\begin{array}{l}\text { Average annual } \\
\text { HDI growth }(\%) \text {, } \\
2008-2013\end{array}$ & $\begin{array}{l}\text { HDI rank, } \\
2012\end{array}$ & $\begin{array}{l}\text { HDI rank } \\
\text { change, } \\
2008-2013\end{array}$ \\
\hline 1 & 2 & 3 & 4 & 5 & 6 & 7 & 8 & 9 \\
\hline \begin{tabular}{|l|} 
Brazil \\
\end{tabular} & 0,731 & No data & 0,739 & 0,740 & 0,742 & 0,67 & 80 & -4 \\
\hline Russia & 0,770 & No data & 0,773 & 0,775 & 0,777 & 0,64 & 57 & 0 \\
\hline India & 0,554 & No data & 0,570 & 0,581 & 0,583 & 1,49 & 135 & 1 \\
\hline China & 0,682 & No data & 0,701 & 0,710 & 0,715 & 1,52 & 93 & 10 \\
\hline
\end{tabular}




\begin{tabular}{|l|c|c|c|c|c|c|c|c|}
\hline 1 & 2 & 3 & 4 & 5 & 6 & 7 & 8 & 9 \\
\hline Germany & 0,902 & No data & 0,904 & 0,908 & 0,911 & 0,51 & 6 & -1 \\
\hline Norway & 0,937 & No data & 0,939 & 0,941 & 0,943 & 0,28 & 1 & 0 \\
\hline the USA & 0,905 & No data & 0,908 & 0,911 & 0,912 & 0,26 & 5 & -2 \\
\hline
\end{tabular}

Source: own study on the basis of United Nations Development Programme, Human Development Index // http:// hdr.undp.org/en/content/table-2-human-development-index-trends-1980-2013 // (accessed on 08/02/2015).

Moving from economic indicators to the more social ones, Happy Planet Index is worth noting. In contrast to previous indicators, it takes into account the impact on the environment of a given society. This is important for the social development approach, considering the future existence of successive generations - a larger, more intense 'ecological footprint' will lead to poorer quality of life. HPI, in addition to the current level of satisfaction of needs takes into account also the future ability of the environment to achieve the objectives of the population. (http://www.neweconomics.org, 12/02/2015)

The index consists of purely qualitative elements, e.g. perceived well-being as well as the more measurable, such as life expectancy. The denominator of the entire system - is the cost ecological footprint. Indicator assumes that the purpose of economic activity is not getting rich (tool), but ensuring health and happiness (aim) for present and future generations. HPI is an indicator standing in opposition to the present primary prism of rating satisfaction and social welfare - by the quantity of consumption. However, this is an important indicator that will be another point on the road to better explanation of the purpose of the country.

HPI alone (Table 4) does not fully reflect the sought "satisfaction/happiness of society". It is only a part of the indicator, besides defined by other variables. Of great importance to the final result (absolute HPI) is an ecological footprint. Its significance and impact on the well-being of individuals is higher in collective and long-term oriented societies. Thus, it may not be important for every nation, e.g. the USA where individualism and capitalist traditions, and the "here and now" approach play a crucial role. This is a serious drawback of HPI. (Aldhous, 2012)

Table 4

Happy Planet Index: 2006, 2009, 2012 (selected countries)

\begin{tabular}{|l|c|c|c|c|c|c|}
\hline \multicolumn{1}{|c|}{ Country } & \multicolumn{6}{c|}{ Happy Planet Index } \\
\hline & 2006 & 2009 & & \multicolumn{2}{c|}{2012} \\
& all HPI & all HPI & all HPI & $\begin{array}{c}\text { Experienced } \\
\text { well-being }\end{array}$ & Life expectancy & $\begin{array}{c}\text { Ecological } \\
\text { footprint }\end{array}$ \\
\hline Brazil & 48,59 & 61,0 & 52,9 & 6,8 & 75,2 & 2,9 \\
\hline Russia & 22,76 & 34,5 & 34,5 & 5,5 & 68,8 & 4,4 \\
\hline India & 42,46 & 53,0 & 50,9 & 5,0 & 65,4 & 0,9 \\
\hline China & 55,99 & 57,1 & 44,7 & 4,7 & 73,5 & 2,1 \\
\hline Germany & 43,83 & 48,1 & 47,2 & 6,7 & 80,4 & 4,6 \\
\hline Norway & 39,18 & 40,4 & 51,4 & 7,6 & 7,1 & 4,8 \\
\hline the USA & 28,83 & 30,7 & 37,3 & 7,2 & 78,5 & 7,2 \\
\hline
\end{tabular}

Source: own study on the basis of the data from: New Economic Fundation // http://www.happyplanetindex.org/ // (accessed on 07/02/2015). 
In terms of absolute HPI, the best of the analyzed countries were Brazil, India and Norway. Expansive development of China and Russia has a strong impact on the environment and the societies. It is evident, however, that the societies of Brazil and Germany are similarly satisfied with their lives. The highest rate of positive social wellbeing was reached by Norwegians and Americans.

The last comparable indicator is "pure happiness". It is difficult to measure as highly subjective. However, it is the individual life satisfaction that shows in which country theoretically „life is better”, which will attract human capital and which can be expected to further lose its potential.

First, it is crucial to determine how happiness is defined by the creators of the index. The authors of the Happiness Report for 2013 recognize happiness as a mixture of positive emotions associated with life. The level of satisfaction is affected by economic factors in the country (poverty or its lack, unemployment), social development of the nation, access to technology, medicine, science, entertainment. (issuu.com/earthinstitute/docs/worldhappinessreport2013_online, 09.02.2015). Attention should also be paid to the cultural aspect. Happiness is perceived differently in Europe, where individualism prevails, e.g. in achieving life goals and development. In Asia, in multiple languages there is no word "I" - there are collective societies, composed of units. Cultural aspects, including the test by G. Hofstede is important here. (http://geert-hofstede. com/countries.html, 02.19.2015). Such discrepancies in individual societies make it difficult to obtain precise result, however, they widen the horizon of research on social satisfaction.

As in the table below (Table 5), in the years 2005-2007 to 2010-2012 the highest positive change in "happiness" was recorded in Russia, Brazil and China. Adverse changes have occurred in India and the USA. Yet, in absolute terms (as the level of happiness of the population) Norway has the second place in the world, the USA - seventeenth. Brazil, occupying the 24th position, is higher in the ranking than the German society. Other BRIC countries occupy distant places.

Table 5

Happy Planet Index (selected years)

\begin{tabular}{|c|c|c|c|c|c|}
\hline \multirow[t]{2}{*}{ Country } & \multicolumn{4}{|c|}{ Happy Planet Index } & \multirow[b]{2}{*}{ Change in percent } \\
\hline & $\begin{array}{l}\text { position in the rank- } \\
\text { ing (report for 2013) }\end{array}$ & $\begin{array}{l}\text { Index value } \\
2010-2012\end{array}$ & $\begin{array}{l}\text { Index value } \\
2005-2007\end{array}$ & $\begin{array}{l}\text { Change in the } \\
\text { index value }\end{array}$ & \\
\hline Brazil & 24 & 6,849 & 6,478 & 0,371 & $5,7 \%$ \\
\hline Russia & 68 & 5,464 & 5,118 & 0,346 & $6,8 \%$ \\
\hline India & 111 & 4,772 & 5,154 & $-0,382$ & $-7,2 \%$ \\
\hline China & 93 & 4,978 & 4,721 & $+0,257$ & $5,4 \%$ \\
\hline Germany & 26 & 6,672 & 6,509 & $+0,163$ & $2,5 \%$ \\
\hline Norway & 2 & 7,655 & 7,392 & $+0,263$ & $3,6 \%$ \\
\hline the USA & 17 & 7,082 & 7,365 & $-0,283$ & $-3,8 \%$ \\
\hline
\end{tabular}

Source: own study on the basis of: World Happiness Report 2013 // issuu.com/earthinstitute/docs/worldhappinessreport2013_online // (referred on 09/02/2015).

These reports are only small pieces of available statistics. On this basis, create tens of indicators may be created, and further combinations thereof, which would allow for more accurate analysis of the issue. However, already on the basis of the above data, it was possible to establish some properties of the individual entities. 


\section{BRIC SOCIETIES INCREASINGLY DEVELOPED? CONCLUSIONS}

Summary of economic and more subjective indicators, relating to personal satisfaction and happiness showed that the level of income of the population is important, but not crucial. Appropriately developed (to socio-cultural development) government policy, as in the case of Brazil, allows a relatively high level of satisfaction with life. The German society's GDP per capita is more than 7 times bigger than in Brazil (Graph 1), still the inhabitants of the latter country declare themselves as "happier".

It should be noted that without a high level of income people are not able to secure their future, and this leads to dissatisfaction (Russia, India). Thus, at least in the initial stage of development of a country is a significant to increase income, which allows for e.g. improvement of living conditions and extension of life expectancy. Important role in this process is played by the authorities, which should take care of the proper redistribution of income and support development activities e.g. through a policy of encouraging education and enabling people to find jobs and develop themselves.

Regardless of the current income level of the society, constant improvement of people's living conditions and a positive outlook for the coming years proves to be important. Thus, the authorities of a given country can create a development model ensuring stability and peace of mind of the public. Also correct positioning of the society which leads to achieving relatively high satisfaction seems essential.

Implemented development must take the environment into account. HPI highlights a problem that can affect many countries. Maintaining an adequate level of happiness in the future may prove particularly difficult for those who have the greatest impact on the environment. The US and China are the leaders in ambient pollution, which in the coming decades can be crucial for the sustainability of their existence. Brazil, despite the success when compared to the rest of the group, still needs a lot of changes. HDI score of the country at the 80 th place shows that this society is still developing. So far, however, the decisions bring positive results. Each of the BRIC countries passed reforms that brought them closer to more developed countries/societies. Convergence theory thus seems to be confirmed in this group. (Rassekh, 1998, pp. 85-105)

Finally, it can be concluded that growth has limits (temporary), and they are not only dependent on material, economic factors. The public might be willing to state that the level reached at a given time is sufficient (to ensure satisfactory consumption). In the long term growth boundaries are constantly shifting due to e.g. technical progress, which enables new forms of undiscovered consumption (unaware need for further consumption, resulting, among others, from limited knowledge of its capabilities).

As a result of observing BRIC and the control group, it can also be said that needs of societies that are at different stages of development are indeed changing. At each of these levels it is, however, possible to achieve a relatively high level of social satisfaction. So it makes sense to go back to the Maslow's pyramid of needs and, referring it to the consumption of particular goods and services, determine which societies are at a higher level of meeting the needs. This can also help to determine which of them are on a higher level of development. So this is a prelude to further research on specifying the notion of a developed society and its definitional distinction with the concept of happiness.

Instability of capital location in the world (high liquidity), the economic crisis started in the US, the economic slowdown in the EU combined with incentives to reduce outsourcing (which in the past years has been a source of growth of, for example, Asian companies) forces greater attention from the authorities to make better use of the slower growth to ensure sustainability of the development of societies. Therefore, in the coming decades BRIC may face a difficult task to „climb” upwards the Maslov's pyramid. (Strelau, 2007, pp. 641-643)

Growth and development are observed in all four BRIC countries. Greater convergence between the two indicators is present in the case of Brazil and China. However, only the Brazilian authorities managed to combine growth and development in such a way to obtain a clear increase in social satisfaction. 


\section{REFERENCES}

Aldhous, P. (2012), US fails on Happy Planet Index, New Scientist, issue 2869, p. 10.

Agenda Terytorialna Unii Europejskiej 2020 //http://www.eu-territorial-agenda.eu/Reference\%20Documents/updated\%20Territorial\%20State\%20and\%20Perspective\%20of\%20the\%20EU_May_2011_FINAL.pdf, (referred on 12/02/2015).

Barton, D., Chen, Y., Jin, A. (2013), Mapping China’s middle class, McKinsey Quarterly, No. 3.

Bastiat, F. (1964), Selectet Essays In Political Economy, New Jersey: Princeton, p. 111.

Bossak, J.W. (2006), Systemy gospodarcze a globalna konkurencja, Warszawa: Wydawnictwo Szkoły Głównej Handlowej, pp. 13-15.

Cameron, R. (2001), Historia gospodarcza świata. Od paleolitu do czasów najnowszych., Warszawa: Wydawnictwo Książka i Wiedza, pp. 11-13.

Costanza, R., Hart, M., Posner, S., Talberth, J. (2009), Beyond GDP: The Need for New Measures of Progress, The Pardee Papers, No. 4.

Cui, A., Song, K., Understanding China's Middle Class // http://www.chinabusinessreview.com/understanding-chinasmiddle-class/, (referred on 17/02/2015).

Kapur D., Vaishnav M., Being middle class in India, The Hindu, // http://www.thehindu.com/opinion/op-ed/beingmiddle-class-in-india/article6673580.ece // (referred on 19/02/2015).

New Economics Foundation, Happy Planet Index // http://www.neweconomics.org/// (referred on 12/02/2015).

Nowa encyklopedia powszechna PWN, (1998), Warszawa: Wydawnictwo Naukowe PWN, s. 616.

O’Neill, J. (2001), Building Better Global Economic BRICs, Global Economics, Paper No: 66. New York: Goldman Sachs, pp. 9-11.

Rassekh, F. (1998), The Convergence Hypothesis: History, Theory, and Evidence, Open economies review, No. 9, Netherland: Kluwer Academic Publishers, pp. 85-105.

Samuelson, P.A., Nordhaus, W.D. (2012), Ekonomia, Poznań: Wydawnictwo Rebis, pp. 402-405;

Milewski, R. (1999), Elementarne zagadnienia ekonomii, Warszawa: PWN, pp. 244-252.

Stownik wspótczesnego języka polskiego, (1998), Warszawa: Wydawnictwo Reader Digest, p. 591.

Global Bank statistics, // http://data.worldbank.org/indicator/NY.GDP.MKTP.KD.ZG // (referred on 11/01/2015).

Global Bank statistics // http://www.google.us/publicdata/explore?ds=d5bncppjof8f9_\&met_y=ny_gdp_mktp_cd\&i $\operatorname{dim}=$ country:POL:UKR:NOR\&hl=pl\&dl=pl\#!ctype=l\&strail=false\&bcs=d\&nselm=h\&met_y=ny_gdp_pcap_ cd\&scale_y=lin\&ind_y=false\&rdim=region\&idim=country:NOR:DEU:RUS:BRA:CHN:IND:USA\&ifdim=regi on\&tstart=793062000000\&tend $=1361142000000 \& \mathrm{hl}=\mathrm{pl} \& \mathrm{dl}=\mathrm{pl} \&$ ind $=$ false $/ /($ referred on 11/01/2015).

Strelau J. (2007), Psychologia. Podręcznik akademicki. Psychologia ogólna, Gdańsk: Gdańskie Wydawnictwo Psychologiczne, pp. 641-643.

Tamazian, A., Piñeiro Chousa, J., Chaitanya Vadlamannati, K. (2009), Does higher economic and financial development lead to environmental degradation: Evidence from BRIC countries, Energy Policy, 37, p. 247.

United Nations Development Programme, Human Development Index // http://hdr.undp.org/en/content/table-2-human-development-index-trends-1980-2013 // (referred on 08/02/2015).

Vaury, A. (2003), Is GDP a good measure of economic progress?, Post-Autistic Economics Review, Issue no. 20, pp. 36-44.

Waligóra, K. (2011), Kraje BRIC potęgi gospodarcze XXI wieku, [in:] Bocian A.F. (ed.), Ekonomia - Polityka - Etyka, Białystok: Wydawnictwo Uniwersytetu w Białymstoku.

Waligóra, K. (2012), Światowy kryzys gospodarczy początku XXI wieku - „New Deal” wg BRICS, [in:] Bocian A.F. (ed.), Globalizacja - Polityka - Etyka, Białystok: Wydawnictwo Uniwersytetu w Białymstoku.

Wąsowski, M., Ropa tanieje - spadki cen zabija rosyjska gospodarkę? Rosja może przez to stracić nawet 1,2 proc. PKB // http://natemat.pl/120697,ropa-tanieje-spadki-cen-zabija-rosyjska-gospodarke-rosja-moze-przez-to-stracic-nawet1-2-proc-pkb // (referred on 20/02/2015). 
website on Geert Hofstede's study // http://geert-hofstede.com/countries.html // (referred on 19/02/2015).

Wielka encyklopedia powszechna PWN, (1968), vol. 10, Warszawa: PWN, p. 148.

World Happiness Report 2013 // issuu.com/earthinstitute/docs/worldhappinessreport2013_online // (referred on 09/02/2015). 